\title{
CONTRIBUTING FACTORS TO ENTREPRENEURIAL ATTRACTIVENESSE
}

\author{
Reggy N. Sarmita \\ Fakultas Ekonomi dan Bisnis Universitas Klabat \\ rsarmita@unklab.ac.id \\ Abraham Lelengboto \\ Fakultas Ekonomi dan Bisnis Universitas Klabat \\ abraham.r@unklab.ac.id
}

\begin{abstract}
The purpose of this study was to find the contributing factors to entrepreneurial attractiveness. The methodology used in this study were quantitative and qualitative approach. Qualitative approach was used to identify the variables in this study, while the quantitative approach was used to group and categorize the variables into determined factors. Forty-four variables were generated from the interviews and furthermore were constructed into a set of questionnaires. The questionnaire was then distributed and filled out by 158 respondents. The findings of this study showed that there were 12 primary factors namely interest, social environment, opportunity, attitude, commitment, support of close person, financial need, wanting to be rich, networking, care, inspiration, and parents. These factors were recognized in this study as the contributing factors to entrepreneurial attractiveness.
\end{abstract}

\section{Keywords: Entrepreneurial Attractiveness, Interest, Social Environment, Opportunity}

\section{Introduction}

The government of Indonesia, through several ministries, have active programs to increase the number of entrepreneurs which aim to strengthen the national economy. The Ministry of Cooperatives and Small and Medium Enterprises stated that the total population of entrepreneurs in Indonesia has only reached $0.43 \%$ of the total population of productive age; while in some neighboring countries, the stated number is very far behind, such as the number of entrepreneurs in Singapore which has reached 7\%, Malaysia 5\%, and Thailand 3\% (www.swa.com, 2016). For this reason, some State-Owned Enterprises such as Bank Mandiri initiated a supporting program intended to stimulate the growth of the total number of entrepreneurs through a contest or competition of young independent entrepreneurs since 2007 (www. wirausahamandiri.co.id, 2016).

A research conducted by Matejovsky, Mohapatra and Steiner (2014) about the dynamic effects of entrepreneurship on regional economic growth that was conducted in Canada concluded that the increased entrepreneurial activities give positive and permanent effect on provincial incomes and can be regarded as a moving engine of the long-run growth.

However, because the research conducted by Matejovsky, Mohapatra and Steiner (2014) did not give any insight on how big should the total number of entrepreneurship be in order for it to contribute a significant effect on the economic growth of a country, the results of a research conducted by Sabella, Farraj, Burbar \& Qaimary (2014) in the Palestinians West Bank concluded that the more the number of entrepreneurs, the more significant the effect will be on the economic growth of a region. 
Taking into account the impact of entrepreneurial activity and the number of entrepreneurs to the economic growth, it is therefore important for researchers to conduct a research on the factors that contribute to entrepreneurial interest. This is because according to Nguyen and Nguyen (2008), the motivation of people to do entrepreneurship is multi-dimensional and this motivation may change with the changing of time.

Many researches have been done to test some motivation that have an influence on entrepreneurial interest, such as research concerning participation in entrepreneurship education program to the desire of becoming entrepreneurs conducted by Rauch and Hulsink (2015). Their study revealed that participation in entrepreneurship education program increases positive attitude towards entrepreneurship. This result supports a previous study conducted by Hao, Seibert \& Hills (2005), as well as research by Chell and Allman (2003) which found that entrepreneurship can be taught. Furthermore, another research conducted by Pihie \& Bagheri (2013), by comparing students at state and private universities in Malaysia, found that the students at public universities have higher interest in entrepreneurship compared to students at private universities.

Based on the existed phenomenon in regard to the interest of entrepreneurship among college students, the researcher wanted to know what are the contributing factors to the entrepreneurial attractiveness of the students of the Faculty of Economics of Universitas Klabat.

In line with the above description, the researcher formulated the research questions in this study as follows: (1) what are the contributing factors to entrepreneurial interest of the students of the Faculty of Economics of Universitas Klabat, and (2) which among the factors have the greatest contribution?

\section{Research Methodology}

The method used in this study was the factor analysis. Factor analysis aims to find information related to the variables under study, which in this case are factors that contribute to entrepreneurial interest. The approach used for this study was exploratory factors analysis (EFA) wherein this approach would discover which factors contribute to certain variables and to analyze which variables have the same measurement that can be categorized into one factor (Yong \& Pearce, 2013).

The population of this study was the students of the Faculty of Economics who were enrolled in the second semester of the academic year 2015/2016. As for the sampling technique, the purposive sampling technique was used with the criteria of being enrolled in the Public Relations and Marketing Entrepreneurship class in the second semester of the academic year 2015/2016. The samples used in this study were 170 students based on the method of determining the number of samples using maximum likelihood (ML), which states that the sample is about $150-400$ respondents or in proportion to the number of items in the question which is $1: 5$, where 1 question is equated to 5 respondents.

The instrument of data collection for this study was a questionnaire that was constructed based on the results of interviews conducted to the student groups. The interviews were conducted directly and in detailed to the objects under study who were students of the Faculty of Economics of Universitas Klabat who took the Public Relations and Marketing Entrepreneurship class in the second semester of 2015/2016 with a total of 50 students. The questions asked were: What makes you interested to become entrepreneurs? From results of the interviews conducted, there were 70 items found, which later became 44 items because there were several answers that were just the same or repetitive. Of these 44 items then was the questionnaire constructed.

The questionnaires were then distributed to 30 students as pilot testing to test the reliability and validity of the instrument to be used. The results of the validity test if they are less than $r$ table 0.316 , then the items are excluded from the questionnaire. Each item that is accompanied by the symbol $*$ and $* *$ is accepted to be valid, and items that are not accompanied by the symbol are declared invalid and should be removed from the questionnaire. 
The reliability test of the instrument had a Cronbach Alpha value of 0.92 , which is greater than the reference value of 0.70 ; thus, the reliability of the instrument of this study is good and can be used as an instrument in this study.

After the instrument had met the reliability and validity testing standard, the questionnaires were distributed to 170 students as respondents of this study, and there were 158 questionnaires that could be used for further testing.

The statistical analyses used in this study underwent the following steps:

Determining the variables that will be analyzed using SPSS by looking at the following values:

The Kaiser-Meyer-Olkin's overall measure of sampling adequacy value must be $>0.6$

The Bartlett's test of sphericity value is significant at $p$ value of $<0.05$.

The diagonal value (a) or measure of sampling adequacy (MSA) seen from the Anti-image Correlation should be $>0.5$; otherwise, the item must be removed from the variable.

Determining the extracted factor; it is necessary to do further statistics testing in reference to the eigenvalues where the value should be $>1$. The eigenvalues is used to determine the number of factors that will be maintained.

Determining the variable's component that can be categorized into factor. At this step, statistical test was used to get the Varimax Rotation value (Rotated Factor Matrix) in which rotation was conducted to maximize the loading factor of each variable. The minimum loading factor value for a variable's component that can be categorized into a particular factor is $>0.4$.

Grouping these variables into existing factors and then naming each of the factors. The highest value of the variables that contribute to a particular factor may be a reference to the name of the factor.

\section{Result and Discussion}

The research method used yielded an assumption testing value that met the criteria in which the Kaiser-Meyer-Olkin's (KMO) value of 0.823 is greater than 0.6 , indicating that the samples used met the total adequate number of total samples. Other value such as the Bartlett's test of sphericity value is less than 0.05 which is 0.00 that shows how strong the correlation among variables.

Table 1

Kaiser-Meyer-Olkin and Bartlett's Test Value

\begin{tabular}{|c|c|c|}
\hline $\begin{array}{l}\text { Kaiser-Meyer-Olkin } \\
\text { Adequacy. }\end{array}$ & Measure of Sampling & .823 \\
\hline \multirow{3}{*}{$\begin{array}{l}\text { Bartlett's Test } \\
\text { Sphericity }\end{array}$} & Approx. Chi-Square & 2810.551 \\
\hline & df & 946 \\
\hline & Sig. & .000 \\
\hline
\end{tabular}

The results of the eigenvalue produced 12 factors that contributed to entrepreneurial attractiveness namely (1) Interest factor, (2) Environment factor, (3) Opportunity factor, (4) Attitude factor, (5) Commitment factor, (6) Support of close person factor, (7) Financial need 
factor, (8) Wanting to be rich factor, (9) Networking factor, (10) Care factor, (11) Inspiration factor, and (12) Parents factor. Overall, the contributing value to entrepreneurial interest amounted to $64.886 \%$ wherein the interest factor accounted for $22.377 \%$, social environment at $8.492 \%$, opportunity at $5.331 \%$, attitude at $4.397 \%$, commitment at $3.884 \%$, support of close person at $3.681 \%$, financial need at $3.346 \%$, wanting to be rich at $3.103 \%$, networking at $2.789 \%$, care at $2.613 \%$, inspiration at $2.543 \%$, and parents at $2.353 \%$.

Each factor is determined by the value of the highest loading factor of several questions with a value greater than $0.5 \%$. Appendix A shows the variables of each of the items that can be categorized into one separate factor.

In appendix A, it can also be seen that the highest loading factor on each factor, where factor 1 is have the interest from within $(r=0.771)$, followed by the desire to achieve success $(r$ $=0.740$ ). The group for factor 1 is having the interest factor. For factor 2 which is the environment factor is it can create job opportunities for other people $(r=0.758)$, followed by influence of the social environment $(r=0732)$, and having the capital for business $(r=0.625)$. Factor 3 namely opportunity is get the chance or opportunity $(r=0.746)$ and difficult to get a job $(r=0.717)$. For factor 4 namely attitude factor is relentless attitude $(r=0.641)$, followed by is creative $(r=0.633)$. Furthermore, factor 5 namely commitment is have commitment $(r=0.772)$, followed by feel pride $(\mathrm{r}=0.690)$. Factor six namely support of close person factor is influenced by girlfriend/boyfriend $(\mathrm{r}=0.787)$, followed by have a sense of responsibility $(\mathrm{r}=0.645)$, and got support $(\mathrm{r}=0.549)$. Factor 7 namely financial needs is economic pressure $(r=0.746)$, followed by the need of money $(\mathrm{r}=0.479)$. For factor 8 namely want to be rich is want to be rich $(\mathrm{r}=0.607)$, followed by have a hobby to become entrepreneur $(\mathrm{r}=0.553)$. Factor 9 namely networking is have broad networking $(\mathrm{r}=0.713)$, followed by dare to take risk $(\mathrm{r}=0.629)$. For factor 10 namely the care factor is to be able to help others $(r=0.777)$, followed by have a firm belief $(r=0.500)$. Factor 11 namely being inspired factor is to be motivated by others $(r=0.755)$, and factor 12 namely parents factor is to help parents $(\mathrm{r}=0.744)$.

In line with that suggested by Gazzaniga, Heatherton and Halpern (2013), every action is based on a motivation, both intrinsic and extrinsic motivation, where intrinsic motivation is motivation to take action because of a value or pleasure associated with these actions; while extrinsic motivation is motivation to take action because of a particular purpose that is directing the action. Relating it to the self-determination theory, it has been found that people are motivated to satisfy their needs such as competence, being connected to others, autonomy, which is a description of personal control.

The twelve factors obtained from the statistical test results are the factors that contribute to entrepreneurial interest. These results are consistent with the theory suggested by Hisrich et.al. (2008) in which entrepreneurial action is more often due to a desire or willingness. Entrepreneurs tend to pursue a definite chance, entering new market and offering new products. The desires capture the driving factors that give effect to an action. Furthermore, it was explained that a perceived desirability depends on the attitude of an individual towards entrepreneurial activity, wherein the higher the perceived desirability of an individual, the more powerful the desire or willingness of the individual to do an entrepreneurial activity. 
Table 3

Factors Category

\begin{tabular}{cc}
\hline No & Factors \\
\hline 1 & Have the interest factor \\
2 & Social environment factor \\
3 & Opportunity factor \\
4 & Attitude factor \\
6 & Commitment factor \\
7 & Support of close person factor \\
8 & Financial need factor \\
9 & Wanting to be rich factor \\
10 & Networking factor \\
11 & Care factor \\
12 & Inspiration factor \\
\hline
\end{tabular}

A research conducted by Carsrud and Brannback (2011) is in line with the results of this study in which the motivation related to entrepreneurship is an important mechanism explanation for various behaviors of entrepreneurs. This motivation will directly affect both the interest and behavior caused by the interest itself.

Social motivation also has an impact on the desire for entrepreneurship (Craig, Mukesh, \& Christopher, 2009). Another study found that the experience of parents and social norms have positive effect on the entrepreneurial interest, whereas gender has no effect (Engle, Schlaegel, \& Dimitriadi, 2011). A research by Jain and Ali (2012) found that the number of entrepreneurs with family backgrounds working in agriculture and private enterprise is more than the number of entrepreneurs with entrepreneur family background.

Consistent with the results of this study are three categories of answer to why some people become entrepreneurs by Barringer and Ireland (2010). The first is wanting to be the boss over oneself; the second is pursuing their ideas, and the third is chasing income financially. Moreover, it was explained that for the entrepreneurs, the desire to be the boss over oneself is driven by a desire to own their own business, and is frustrated by the usual kind of work, and the desire to realize the ideas that they have as well as pursuing their ideas.

Some categories of motivation based on the results of a research conducted by Chedli (2016) to obtain answers on the importance of intrinsic motivation that has a role to a decision in the field of entrepreneurship and performance of a new enterprise is in line with the results of this study. Among the categories, there are four categories of motivation in regards to decision and performance in the field of entrepreneurship. The four categories are favorable conditions, motivation related to social life, motivation related to financial, and trade-related motivation. This study also found three factors that can be used as a tool to measure entrepreneurial performance which are impulse that generates a desire, efficiency, and effectiveness. 


\section{Conclusion}

This research was conducted to find the contributing factors to entrepreneurial attractiveness. The samples used in this study were the students of the Faculty of Economics of Universitas Klabat who were enrolled in the Entrepreneurship Marketing and Public Relations class in the second semester of academic year 2015/2016.

The results of this study found 12 factors that contributed to entrepreneurial interest, in which each of these factors has variables that are categorized into each of the respective factors. The twelve factors are: interest, social environment, opportunity, attitude, commitment, support of close person, financial need, wanting to be rich, networking, care, inspiration, and parents.

\section{References}

(2016, February 2). Retrieved from www.swa.com.

(2016, February 2). Retrieved from www.wirausahamandiri.co.id.

Barringer, B. R., \& Ireland, D. R. (2010). Entrepreneurship. New Jersey: Pearson.

Bolton, B., \& Thompson, J. (2002). Entrepreneurs. Oxford: Butterworth-Heinemann.

Carsrud, A., \& Brannback, M. (2011). Entrepreneurial motivation: What do we still need to know? Journal of Small Business Management, 9 - 26.

Chedli, M. K. (2016). Entrepreneurial motivation and performance of enterprises. Economic, Management, Financial Markets, 175 - 188.

Chell, E., \& Allman, K. (2003). Mapping the motivations and intentions of technology orientated entrepreneurs. R\&D Management, 33(2), 117-132.

Craig, V., Mukesh, S., \& Christopher, M. (2009, December). Enabling the original intent: Catalysts for social entrepreneurship. Journal of Business Ethics, 90(3), 419-428.

Engle, R. L., Schlaegel, C., \& Dimitriadi, N. (2011). Institutions and entrepreneurial intent: A cross-country study. Journal of Developmental Entrepreneurship, 16(2), 227-250. doi:10.1142/S1084946711001811

Field, A. (2005). Dicovering statistics using SPSS (2nd ed.). London: Sage.

Gazzaniga, M., Heatherton, T., \& Halpern, D. (2013). Psychological science. New York: W.W. Norton \& Company, Inc.

Hao, Z., Seibert, S. E., \& Hills, G. E. (2005). The mediating role of self-efficacy in the development of entrepreneurial intentions. Journal of Applied Psychology, 90(6), 12651272. doi:10.1037/0021-9010.90.6.1265

Hisrich, R. D., Peters, M. P., \& Shepherd, D. A. (2008). Entrepreneurship. New York: McGrawHill.

Ireland, R. D., \& Webb, J. W. (2007). A Cross-Disciplinary Exploration of Entrepreneurship Research. Journal of Management, 891-927.

Jain, R., \& Ali, S. W. (2012, July). Entreprenuerial motives of Indian entreprenuers: An empirical study. The Indian Journal of Industrial Relations, 48(1), 59-80.

Jakopec, A., Miljkovic Krecar, I., \& Susanj, Z. (2013). Predictor of entrepreneurial intentions of students of economics. Studia Psychologica, 289 - 297. 
Matejovsky, L., Mahopatra, S., \& Steiner, B. (2014, December). The Dynamic Effects of Entrepreneurship on Regional Economic Growth: Evidence from Canada. Growth and Change, 45(4), 611-639. doi:10.1111/grow.12055

Nguyen, H.-H. D., \& Nguyen, N. T. (2008). Examining personal values and entrepreneurial motives of Vietnamese entrepreneurs in the 21st Century: Two Empirical Studies. African and Asian Studies, 7, 141-171. doi:10.1163/15692100X318709

Pihie, Z. A., \& Bagheri, A. (2013). Student' entrepreneurial regulation and intention to become an entrepreneur: A comparison between public and privat universities. S.Afr.J. Bus. Management, 44(4), 25-35.

Rauch, A., \& Hulsink, W. (2015). Putting entrepreneurship education where the intention to act lies: An investigation into the impact of entrepreneurship education on entrepreneurial behavior. Academy of Management Learning \& Education, 14(2), 187-204. doi:10-.5465/amle.2012.0293

Rofi, A. N. (2012). PENGARUH DISIPLIN KERJA DAN PENGALAMAN KERJA TERHADAP. Jurnal Ilmu Manajemen dan Akuntansi Terapan, 3(1), 1-21.

Sabella, A. R., Farraj, W. A., Burbar, M., \& Qaimary, D. (2014). Entrepreneurship and Economic Growth in West Bank, Palestine. Journal of Developmental Entrepreneurship, 19(1), 1-15. doi:10.1142/S1084946714500034

Umar, H. (2009). Metode Penelitian untuk skripsi dan tesis bisnis. Jakarta: Penerbit Rajawali Pers PT. Raja Grafindo Persada Jakarta.

Yong, A. G., \& Pearce, S. (2013). A Beginner's Guide to Factor Analysis: Focusing on Exploratory Factor Analysis. Tutorials in Quantitative Methods For Psychology, 9(2), 7994. 